\title{
Momordica charantia (Bitter Melon) Reduces Obesity- Associated Macrophage and Mast Cell Infiltration as well as Inflammatory Cytokine Expression in Adipose Tissues
}

\author{
Bin $\mathrm{Bao}^{\circledR}$, Yan-Guang Chen ${ }^{\circledR}$, Lei Zhang, Yan Lin Na Xu, Xin Wang, Jian Liu*, Wei Qu* \\ School of Biotechnology and Food Engineering, Hefei University of Technology, Hefei, China
}

\begin{abstract}
Obesity is a world-wide epidemic disease that correlates closely with type 2 diabetes and cardiovascular diseases. Obesity-induced chronic adipose tissue inflammation is now considered as a critical contributor to the above complications. Momordica charantia (bitter melon, BM) is a traditional Chinese food and well known for its function of reducing body weight gain and insulin resistance. However, it is unclear whether BM could alleviate adipose tissue inflammation caused by obesity. In this study, C57BL/6 mice were fed high fat diet (HFD) with or without BM for 12 weeks. BM-contained diets ameliorated HFD-induced obesity and insulin resistance. Histological and real-time PCR analysis demonstrated BM not only reduced macrophage infiltration into epididymal adipose tissues (EAT) and brown adipose tissues (BAT). Flow cytometry show that BM could modify the M1/M2 phenotype ratio of macrophages in EAT. Further study showed that BM lowered mast cell recruitments in EAT, and depressed pro-inflammatory cytokine monocyte chemotactic protein-1 (MCP-1) expression in EAT and BAT as well as interleukin-6 (IL-6) and tumor necrosis factor- $\alpha$ (TNF- $\alpha$ ) expression in EAT. Finally, ELISA analysis showed BM-contained diets also normalized serum levels of the cytokines. In summary, in concert with ameliorated insulin resistance and fat deposition, BM reduced adipose tissue inflammation in diet-induced obese (DIO) mice.
\end{abstract}

Citation: Bao B, Chen Y-G, Zhang L, Na Xu YL, Wang X, et al. (2013) Momordica charantia (Bitter Melon) Reduces Obesity-Associated Macrophage and Mast Cell Infiltration as well as Inflammatory Cytokine Expression in Adipose Tissues. PLoS ONE 8(12): e84075. doi:10.1371/journal.pone.0084075

Editor: Jörg Hermann Fritz, McGill University, Canada

Received May 10, 2013; Accepted November 19, 2013; Published December 17, 2013

Copyright: $\odot 2013$ Bao et al. This is an open-access article distributed under the terms of the Creative Commons Attribution License, which permits unrestricted use, distribution, and reproduction in any medium, provided the original author and source are credited.

Funding: This work was supported by a project from National Natural Science Foundation of China (Grant No. 31171315) (J.L.); Specialized Research Fund for the Doctoral Program of Higher Education of China (Grant No. 20100111110009 and 20110111120025 to J.L. and W.Q.); Anhui Provincial Natural Science Foundation of China (Grant No. 11040606M92 to J.L.); The Fundamental Research Funds for the Central Universities, China (Grant No.

2012HGCX0003 and 2011HGB21280, 2012HGQC0019 to J.L. and B.B.); China Postdoctoral Science Foundation (Grant No. 2013 M541817 to B.B.); and Foundation of Anhui Educational Committee (Grant No.KJ2011A214 to W.Q.). The funders had no role in study design, data collection and analysis, decision to publish, or preparation of the manuscript.

Competing interests: The authors have declared that no competing interests exist.

*E-mail: liujian509@hfut.edu.cn (JL); quweiok@gmail.com (WQ)

- These authors contributed equally to this work.

\section{Introduction}

Obesity is a world-wide epidemic disease that correlates closely with many metabolic abnormalities, such as type 2 diabetes and cardiovascular diseases [1-3]. During the initiation and progression of diet-induced obesity, along with body weight gain, various inflammatory cells, including macrophages $[4,5]$, mast cells $[5,6]$ and lymphocytes $[7,8]$ infiltrate into adipose tissues. Their infiltration disturbs the balance among the immune cells in adipose tissues, for example the ratio of "classically activated" (M1-type) versus "alternatively activated" (M2-type) macrophages was elevated [9]. Thus in obese individuals, the adipose tissues possess hypertrophic adipocytes and more inflammatory cells and produce more proinflammation mediators, including cytokines, chemokines and hormones [10]. The mediators either assemble in or leak out of adipose tissues, leading to the enhancement of inflammation levels in local tissues and/or sera. Finally, the pathological events further exacerbate fat deposition and obesity-related insulin resistance $[10,11]$. Although the mechanisms are not sufficiently clear, obesity-associated adipose tissue inflammation has been regarded as an important contributing factor to the above metabolic diseases $[10,11]$.

Momordica charantia (bitter melon, BM) is a popular nutritious and healthy vegetable in Asian countries, and it is also used as traditional anti-diabetes and anti-obesity medicine in these areas $[12,13]$. In the past few years, the beneficial effects of BM or its extracts on obesity and obesity-associated insulin resistance were continuously affirmed in various experimental animals, including mice [14-20] and rats [21-23]. The related mechanistic study indicated that BM or its constituents might enhance AMP-associated protein kinase 
(AMPK) [14,15], peroxisome proliferator activating receptors (PPARs) $[16,17]$ and insulin [18-21] signals in tissues, reduce lipogenic gene expression in adipose tissues [22], and increase lipid oxidation in adipose tissues [23]. With regard to obesityassociated inflammation, dietary BM can suppress proinflammatory mediator leptin and resistin levels in adipose tissues [16] and plasma [16,20], elevate system levels of antiinflammatory mediator adiponectin [17] and improve system and brain inflammation [24] in mice fed with high fat diets (HFD). However, it is little known whether BM could reduce the levels of adipose tissue inflammation, including inflammatory cells and cytokines, in diet-induced obese (DIO) mice. Therefore, study of BM anti-inflammation mechanism is necessary and meaningful.

In this study, we investigated the effects of BM on adipose tissue inflammatory cell infiltration and cytokine expression caused by obesity. BM-contained diets ameliorated HFDinduced obesity and insulin resistance. Meanwhile, BM not only reduced macrophage infiltration into EAT and BAT, but also modified the M1/M2 phenotype ratio of macrophages in these tissues. Further study showed that BM lowered mast cell recruitments in EAT, and depressed pro-inflammatory cytokine monocyte chemotactic protein-1 (MCP-1) expression in EAT and BAT as well as interleukin-6 (IL-6) and tumor necrosis factor- $\alpha$ (TNF- $\alpha)$ expression in EAT. Finally, BM-contained diets also normalized serum levels of the cytokines. In summary, BM ameliorated insulin resistance and fat deposition, and reduced adipose tissue inflammation in DIO mice.

\section{Materials and Methods}

\section{BM}

Fresh BM fruits were purchased from the local market. The sample was identified by Prof. Zhou Zhong Ze from School of Resources and Environmental Engineering, Anhui University, China and a voucher (NO. MC20110924) is deposited in Herbarium of School of Biotechnology \& Food Engineering, Hefei University of Technology, China. According to Huang et al. [22], BM fruits were washed with tap water, and then cut into small pieces, freeze-dried at $-40^{\circ} \mathrm{C}$, followed by powdering and stored at $-20^{\circ} \mathrm{C}$.

\section{Mice}

Five-week-old male C57BL/6 mice were purchased from Vital River Laboratory Animal Technology Co. Ltd. (Beijing, China). Hefei University of Technology Standing Committee on Animals approved all animal protocols. All mice were housed in ventilated cages within a pathogen-free barrier facility that maintained a 12-hour light/12-hour dark cycle and allowed free access to autoclaved water and irradiated food. To examine the effect of BM on diet-induced obesity and diabetes, the mice were randomly divided into 6 treatment groups: group 1, were fed on HFD $(n=8)$; group 2, were fed on HFD supplemented with $2 \%$ BM $(n=8)$; group 3, were fed on HFD supplemented with $5 \%$ BM ( $n=8)$; group 4, were fed on low food diet (LFD) $(n=8)$; group 5 , were fed on LFD supplemented with $2 \%$ BM $(n=8)$; group 6 , were fed on LFD supplemented with $5 \%$ BM $(n=8)$. HFD and LFD were based on Research Diets D12451
Table 1. The composition of diets used in experiment ${ }^{1}$.

\begin{tabular}{|c|c|c|c|c|c|c|}
\hline Ingredient (g) & HFD & $\begin{array}{l}\text { HFD } \\
+2 \% B M\end{array}$ & $\begin{array}{l}\text { HFD } \\
+5 \% B M\end{array}$ & LFD & $\begin{array}{l}\text { LFD } \\
+2 \% \mathrm{BM}\end{array}$ & $\begin{array}{l}\text { LFD } \\
+5 \% \mathrm{BM}\end{array}$ \\
\hline Casein & 200 & 200 & 200 & 200 & 200 & 200 \\
\hline L-Cystine & 3 & 3 & 3 & 3 & 3 & 3 \\
\hline Corn starch & 72.8 & 62.03 & 45.9 & 315 & 301.76 & 282.03 \\
\hline Maltodextrin 10 & 100 & 100 & 100 & 35 & 35 & 35 \\
\hline Sucrose & 172.8 & 172.8 & 172.8 & 350 & 350 & 350 \\
\hline Cellulose & 50 & 43.61 & 34 & 50 & 42.14 & 30.22 \\
\hline Soybean oil & 25 & 25 & 25 & 25 & 25 & 25 \\
\hline Lard & 177.5 & 177.5 & 177.5 & 20 & 20 & 20 \\
\hline Mineral Mix 10026 & 10 & 10 & 10 & 10 & 10 & 10 \\
\hline $\begin{array}{l}\text { Dicalcium } \\
\text { phospate }\end{array}$ & 13 & 13 & 13 & 13 & 13 & 13 \\
\hline Calcium carbonate & 5.5 & 5.5 & 5.5 & 5.5 & 5.5 & 5.5 \\
\hline Potassium citrate & 16.5 & 16.5 & 16.5 & 16.5 & 16.5 & 16.5 \\
\hline $\begin{array}{l}\text { Vitamin Mix } \\
\text { V10001 }\end{array}$ & 10 & 10 & 10 & 10 & 10 & 10 \\
\hline Choline bitartrate & 2 & 2 & 2 & 2 & 2 & 2 \\
\hline Freeze-dried BM ${ }^{2}$ & 0 & 17.16 & 42.9 & 0 & 21.1 & 52.75 \\
\hline Total weight (g) & 858.1 & 858.1 & 858.1 & 1055 & 1055 & 1055 \\
\hline Total energy (kcal) & 4057 & 4057 & 4057 & 4057 & 4057 & 4057 \\
\hline \multicolumn{7}{|c|}{$\begin{array}{l}\text { 1. High fat diet (HFD) was based on the Research Diets D12451 diet, and low fat } \\
\text { diet (LFD) was based on the Research Diets D12450B diet. }\end{array}$} \\
\hline
\end{tabular}

diet (45 kcal\% fat) and D12450B diet (10 kcal\% fat) respectively. The detailed contents of all 6 diets were shown in Table 1. The body weights and food intakes of mice were measured at the same time of every week. At 17-week-old, the mice were sacrificed by $\mathrm{CO}_{2}$, and their sera and related fat tissues, including EAT, SAT and BAT were harvested and stored at $-80^{\circ} \mathrm{C}$.

\section{Insulin tolerance tests and glucose tolerance tests}

According to standard protocol [6], insulin tolerance tests (ITT) and glucose tolerance tests (GTT) were performed before the mice were sacrificed. Briefly, to carry out ITT or GTT, fasted overnight mice were injected intraperitoneal with insulin (1.5U/kg bodyweight, WanBang BioPharma) or glucose $(1 \mathrm{~g} / \mathrm{kg}$ bodyweight, Sigma) respectively. The blood samples were taken from mice tail tip. Blood glucose concentrations were measured by a blood glucose meter (Omnitest Plus, B.BRAUN, Kyunggi, Korea) at the time before injection and $15 \mathrm{~min}, 30$ min, $45 \mathrm{~min}, 60 \mathrm{~min}, 90 \mathrm{~min}, 120 \mathrm{~min}$ after injection.

\section{Histology and immunohistochemistry}

Harvested tissue specimens were fixed in $4 \%$ formalin for 24 hours at room temperature, embedded in paraffin and cut into five micron thick sections. All tissue sections were baked at $80^{\circ} \mathrm{C}$ for $20 \mathrm{~min}$ and de-paraffin in xylene at $50^{\circ} \mathrm{C}$ for $30 \mathrm{~min}$ and rehydrated in a graded ethanol series. To test adipocyte sizes, macrophage positive area and the numbers of mast cells in adipose tissues, we performed haematoxylin-eosin staining, 
Table 2. Primers for quantitative real-time PCR.

\begin{tabular}{|c|c|c|}
\hline Gene & Sequence of forward primers $\left(5^{\prime}\right.$ to $\left.3^{\prime},\right)$ & Sequence of reverse primers $\left(5^{\prime}\right.$ to $\left.3^{\prime},\right)$ \\
\hline$F 4 / 80$ & CTTTGGCTATGGGCTTCCAGTC & GCAAGGAGGACAGAGTTTATCGTG \\
\hline Itgax & CTGGATAGCCTTTCTTCTGCTG & GCACACTGTGTCCGAACTC \\
\hline Inos & ССАAGСССТСАССТАСТTCC & CTCTGAGGGCTGACACAAGG \\
\hline Chi3/3 & AGAAGGGAGTTTCAAACCTGGT & GTCTTGCTCATGTGTGTAAGTGA \\
\hline Cd163 & CCTGGATCATCTGTGACAACA & TCCACACGTCCAGAACAGTC \\
\hline$m M c p-6$ & GCCCAGCCAATCAGCG & CCAGGGCCACTTACTCTCAGA \\
\hline Mcp-1 & CCCCAAGAAGGAATGGGTCC & GGTTGTGGAAAAGGTAGTGG \\
\hline $11-6$ & ССТТССТАССССААТТТССАА & AGATGAATTGGATGGTCTTGGTC \\
\hline Tnf- $\alpha$ & ACGGCATGGATCTCAAAGAC & AGATAGCAAATCGGCTGACG \\
\hline Leptin & GAGACCCCTGTGTCGGTTC & CTGCGTGTGTGAAATGTCATTG \\
\hline Ucp-1 & СACTCAGGATTGGCCTCTACG & GGGGTTTGATCCCATGCAGA \\
\hline
\end{tabular}

immunohistochemistry with anti-Mac-2 monoclonal antibody (1:400, BioLegend) and toluidine blue staining, respectively. For measurement of macrophage positive area, 5 random fields each section were evaluated by detecting staining intensity with the Image-Pro Plus Version 6.0 (Media Cybernetics, Inc, Shanghai, China) and data were presented as positive cells area percent (\%) in the tissues. Mast cell numbers in each section were counted under a light microscope (OPTEC), and data were presented as cell numbers per $\mathrm{mm}^{2}$.

\section{RNA extraction and quantitative real-time PCR}

Total RNA was extracted from frozen tissues $(100 \mathrm{mg})$ using TRIzol reagent (TaKaRa, Dalian, China). The cDNAs were synthesized using superscript III reverse transcriptase and oligo $d(T) 18$ primers according to manufacturer's protocol (Invitrogen). Real-time quantitated PCR was performed using the power SYBR green mix (TaKaRa) as previously described [25]. The primer sequences of all tested genes were listed in Table 2.

\section{Stromal vascular fraction (SVF) isolation and Flow cytometry}

EAT from male C57BL/6 mice were excised and minced in PBS. Tissue suspensions were centrifuged $400 \mathrm{~g}$ for 5 minutes to remove free leukocytes. Then tissue was incubated in 2 $\mathrm{mg} / \mathrm{ml}$ collagenase (Sigma-Aldrich) at $37^{\circ} \mathrm{C}$ for 30 minutes with shaking. A 75- $\mu \mathrm{m}$ filter were used to remove adipocyte. After a spin at $400 \mathrm{~g}$ for 5 minutes, SVF pellet were collected in the bottom. The SVF pellet was resuspended in PBS, then RBC Lysis Buffer was added and incubated for 5 minutes. After washing by PBS, cells were incubated with Fc Block (BD Biosciences, San Diego, USA) for 15 minutes on ice [9]. Then antibodies against F4/80 -APC, CD11b- PerCP-Cy5.5, CD11cPE, CD206-FITC (eBioscience, San Diego, USA) were added, and incubated for 30 minutes on ice followed by 2 washes in PBS. Then cells were analyzed by FACS (FACSVerse; BD Biosciences). Data were analyzed on FlowJo software.

\section{ELISA}

The serum levels of IL-6, TNF- $\alpha$, MCP-1, leptin and insulin were measured using corresponding mouse ELISA kits (BD Bioscience, San Diego, USA) according to manufacturer's protocols.

\section{Statistical analysis}

All data were present as means \pm SEM, and the difference between groups was assessed by Mann-Whitney test owing to our small data size and non-normal distribution data $P<0.05$ was considered statistically significant.

\section{Results}

\section{Bitter melon ameliorated fat deposition and insulin resistance}

To induce obesity or test the effects of BM on obesity, we fed the mice with HFD or HFD supplemented with $2 \%$ or $5 \%$ BM for 12 weeks, and the mice fed with LFD or LFD contained the same percent BM were used as controls (detailed composition of diets are shown in Table 1). As we expected, HFD led to a higher body weight gain in mice compared with LFD (Figure 1A). The increased trend in body weight gain was attenuated sharply in mice fed on HFD supplemented with either $2 \%$ or $5 \%$ $\mathrm{BM}$, while there was no similar body weight reduction occurred among 3 groups of mice fed with LFD (Figure 1A). To clarify the possible mechanism that $\mathrm{BM}$ inhibited body weight gain in mice with HFD, we tested food intakes per week of mice and determined their fat weights and adipocyte sizes in EAT, SAT, and BAT at 17-week-old. The results showed that BMcontained diets had no effects on food intakes of mice (Figure $1 \mathrm{G})$, but $2 \%$ or $5 \%$ BM supplement significantly reduced all tested adipose tissue weights (Figure 1B) and adipocyte sizes (Figure 2) in mice with HFD. Such an effect was not observed in mice fed with LFD (Figure 1B and Figure 2). Along with lower body weights, the mice fed on BM-contained HFD had improved insulin sensitivity (Figure $1 \mathrm{C}$ ) and glucose tolerance (Figure 1D) compared with those mice fed only on HFD. Correspondingly, serum insulin and leptin (Figure 1E and $1 \mathrm{~F}$ ) levels were reduced in the mice. 

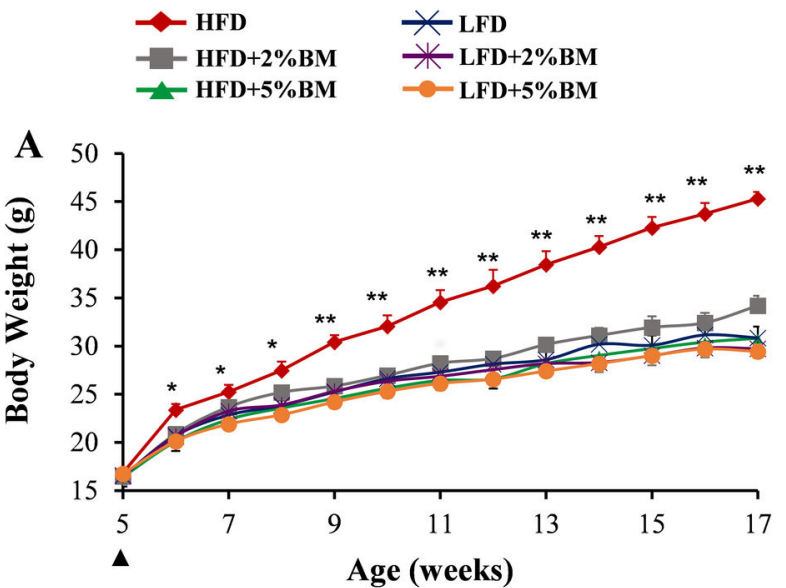

Start fed

C

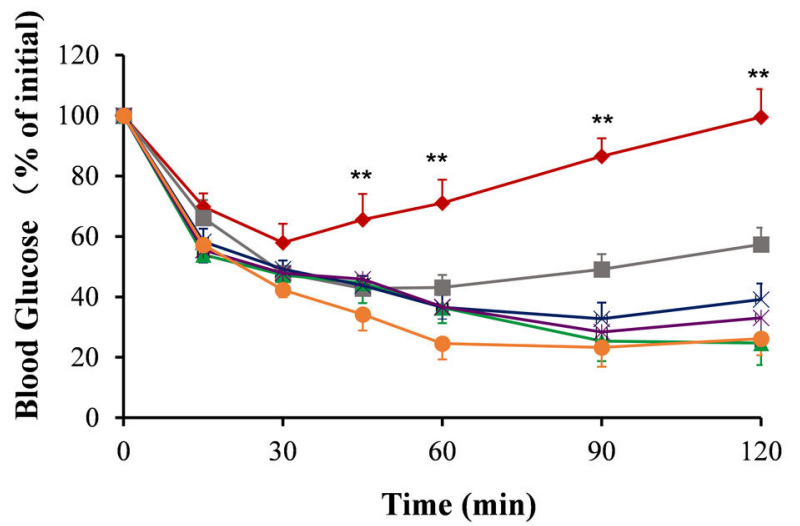

$\mathbf{E}$

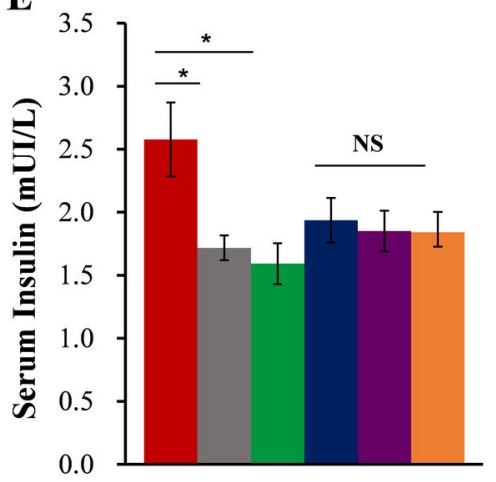

$\mathbf{F}$

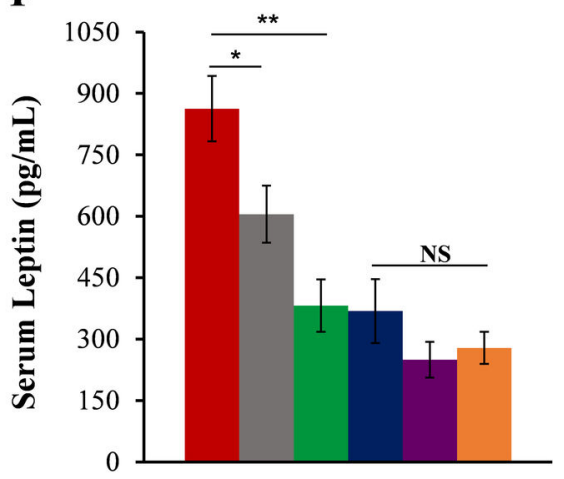

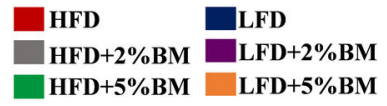

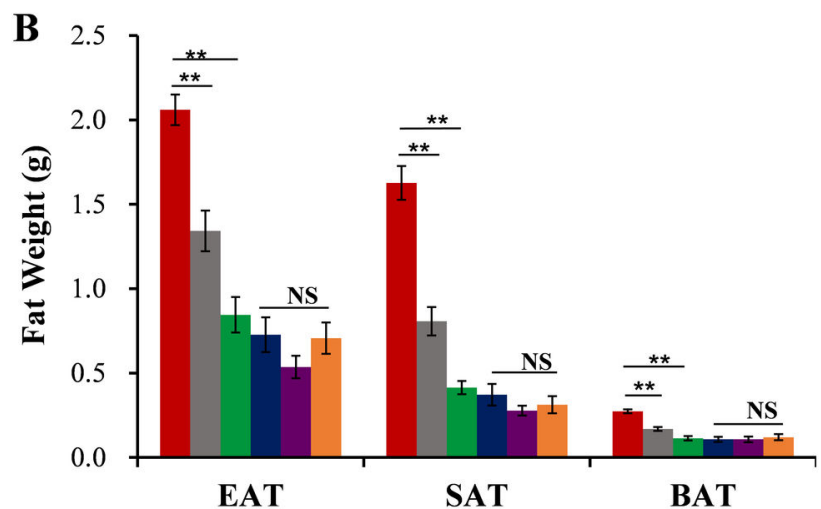

D

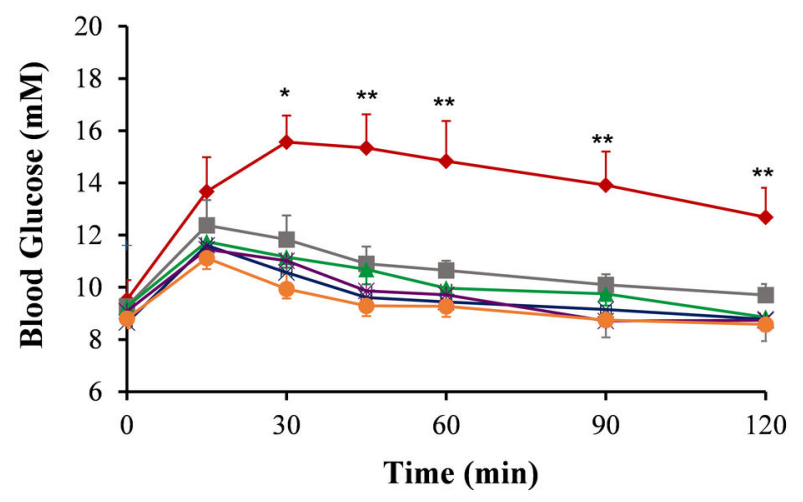

G

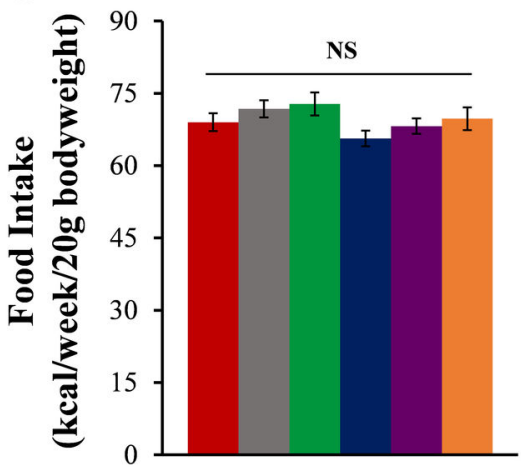

Figure 1. Bitter melon ameliorated fat deposition and insulin resistance in mice fed with HFD. Five-week-old male C57BL/6 mice were grouped and fed on the diets indicated in Table 1. (A) Body weight gain of the mice. (B) The weights of epididymal adipose tissues (EAT), subcutaneous adipose tissues (SAT) and brown adipose tissues (BAT) of the mice. (C) Insulin tolerance and (D) glucose tolerance assays were performed at 17-week-old in the mice. The insulin (E) and leptin (F) concentrations in serum of mice. (G) The energy intake per $20 \mathrm{~g}$ bodyweight of mice during 12-week treatment. Statistical difference between groups is shown using a nonparametric Mann-Whitney test. $n=8$ per group. ${ }^{*} P<0.05$, ${ }^{* \star} P<0.01$. All data are means \pm SEM.

doi: 10.1371/journal.pone.0084075.g001 
A

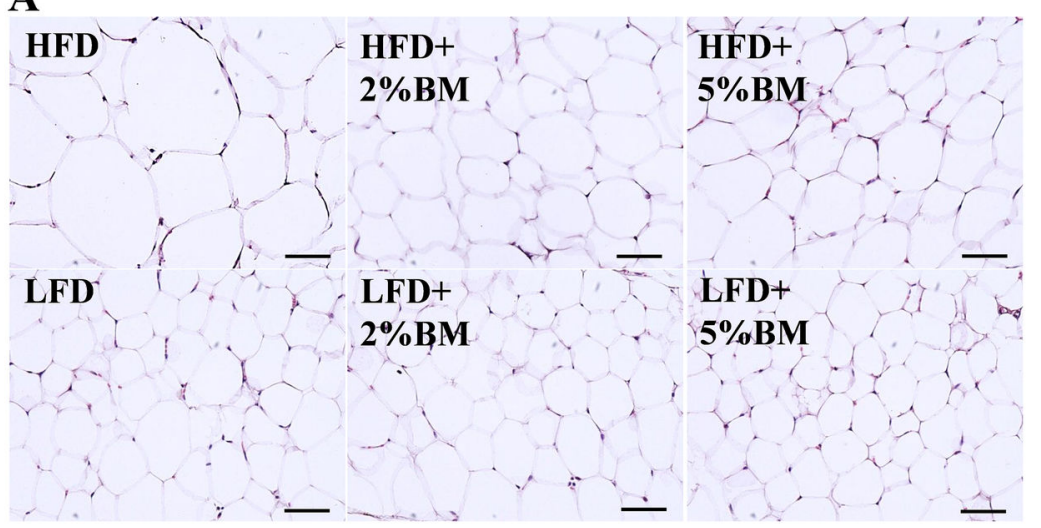

C

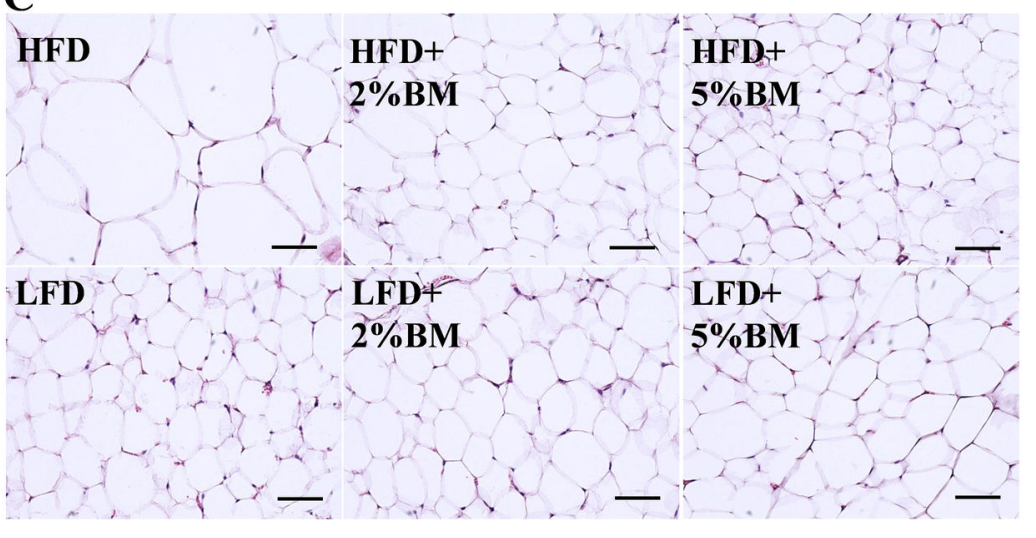

B

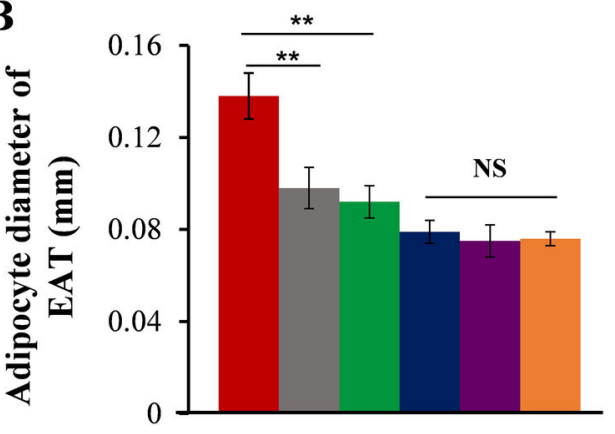

D

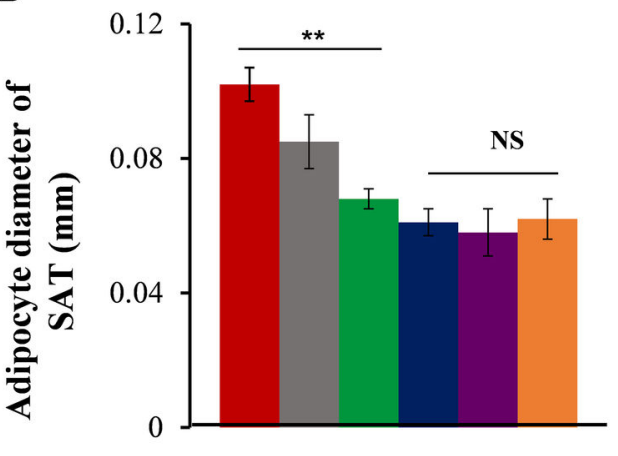

Figure 2. Bitter melon reduced adipocyte size in mice fed with HFD. HE staining of EAT (A) and SAT (C) in mice, scale bars are $50 \mu \mathrm{m}$ in the length. (B) Quantification of EAT adipocyte diameter and (D) SAT adipocyte diameter. (Data were collected from H\&E-stained sections from eight individual mice, five fields per mouse, using Image-Pro Plus 6.0 software) Statistical difference between groups is shown using a nonparametric Mann-Whitney test. $\mathrm{n}=8$ per group. ${ }^{*} P<0.05$, ${ }^{* *} P<0.01$. All data are means \pm SEM. doi: 10.1371/journal.pone.0084075.g002

\section{Bitter melon inhibited the recruitments of inflammatory macrophages into EAT and BAT}

Adipose tissue inflammation is a key hallmark of obesity and obesity-associated insulin resistance $[10,11]$. To test the impact of dietary BM on adipose tissue inflammation, we firstly examined the distribution of macrophages in EAT, SAT and BAT.

Immunohistochemistry staining with monoclonal antibody Mac-2 detected significantly larger macrophage positive corona-areas in EAT (Figure $3 \mathrm{~A}$ and $3 \mathrm{~B}$ ) and BAT (Figure 3B), but not in SAT (Figure 3B), from obese mice fed with HFD than those from lean mice fed with LFD. BM-contained diets reduced potently the trend in mice with HFD (Figure $3 \mathrm{~A}$ and $3 \mathrm{~B})$. Expression of $F 4 / 80$, the common marker of macrophage, is consistent with the immunohistochemistry results (Figure $3 \mathrm{C})$. Mutlicolour flow cytometry was used to confirm the subsets of macrophages in EAT. BM induced a phenotypic switch in macrophage polarization in EAT (Figure 4). BMcontained diets significantly decreased the high proportion of M1 that caused by HFD (Figure 4B), and relatively increased the proportion of $M 2$ in total macrophages in EAT (Figure 4C).
Further, we investigated the expression of Itgax and Inos (specific markers for M1 macrophage), and Cd163 and Chil3I (specific markers for M2 macrophage) [9,26]. BM-contained diets also significantly reduced mRNA expressions of Itgax (Figure 5A) and Inos (Figure $5 \mathrm{~B}$ ) in EAT and BAT of mice with HFD, but mRNA expressions of Cd163 (Figure 5C) and Chil3I (Figure 5D) were not affected in these mice. The results imply BM-contained diets not only inhibit the recruitments of macrophages into EAT and BAT, but also modify the unnatural ratio of $\mathrm{M} 1 / \mathrm{M} 2$ in these adipose tissues in mice with HFD.

\section{Bitter melon decreased the numbers of mast cells in EAT}

Mast cell is a crucial inflammatory cell in diet-induced obesity and diabetes [6,11]. Our pervious study reported that there were more mast cells in EAT in DIO mice than those in lean mice. By contributing to mouse adipose tissue cysteine protease cathepsin expression, apoptosis and angiogenesis, the cells are involved in diet-induced obesity and glucose intolerance [6]. Using toluidine blue staining, we found that HFD induced an increased mast cell recruitment in EAT (Figure 
A

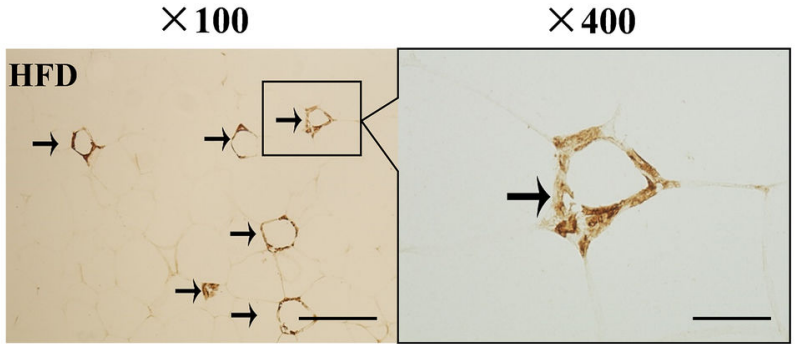

HFD+
$2 \% B M$

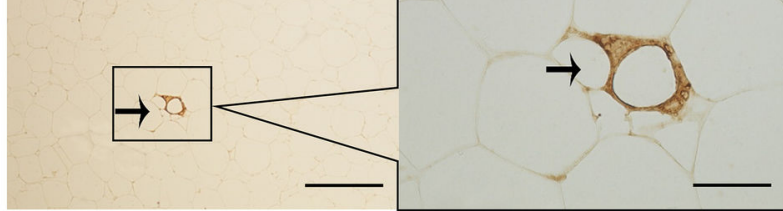

\section{HFD+} $5 \% B M$
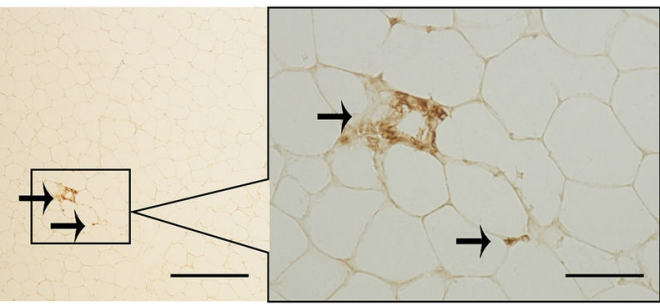
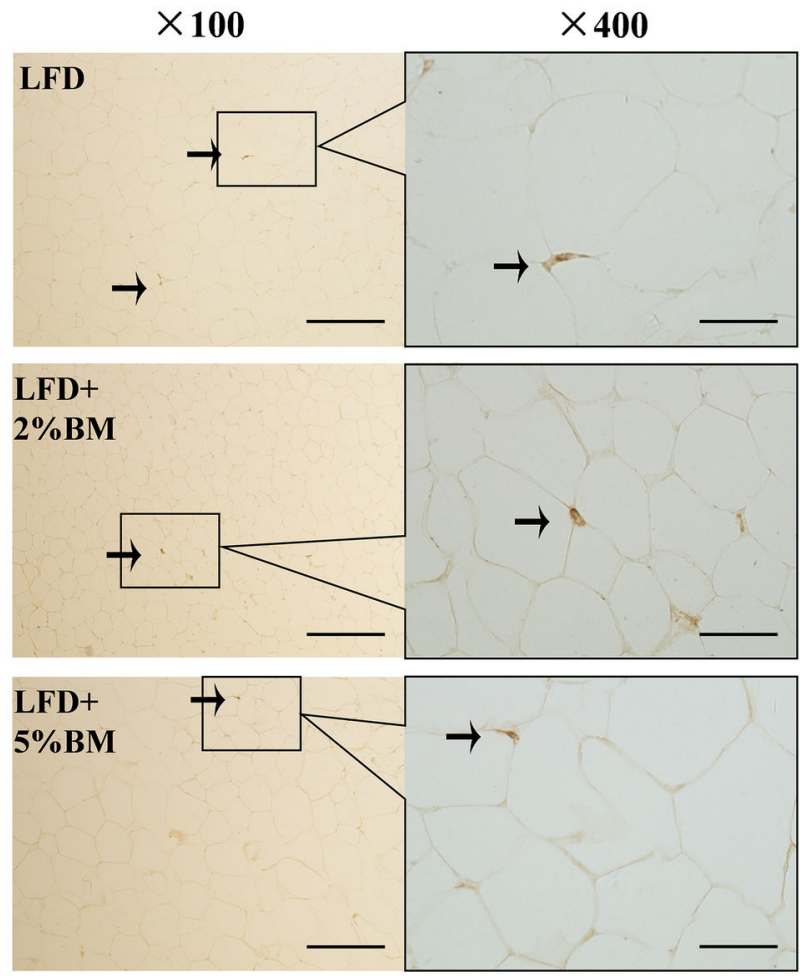

B

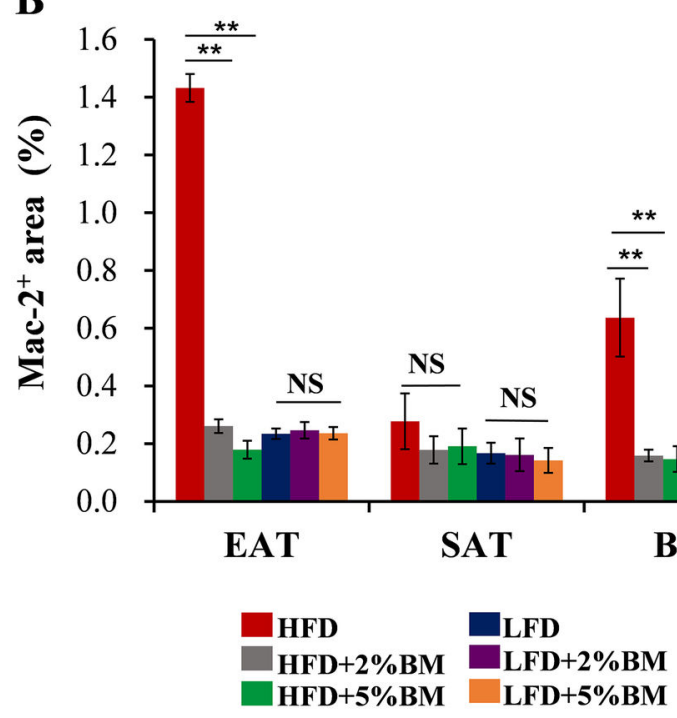

C

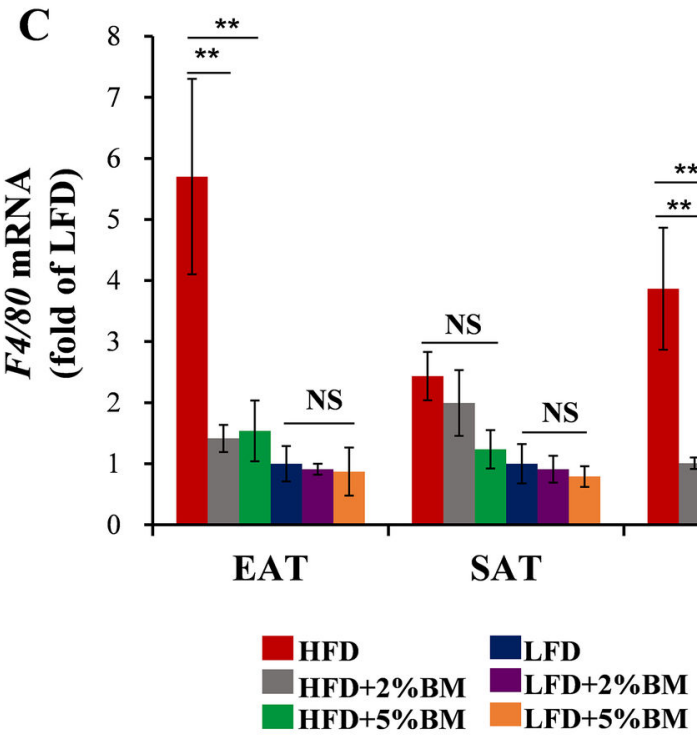

Figure 3. Bitter melon inhibited the recruitments of inflammatory macrophages into EAT and BAT in mice. (A) Mac-2 immunostaining in EAT of mice; arrows indicate Mac- $2^{+}$macrophages; scale bars in $(A), 100 \mu m$ in length in low power views $(\times 100)$ and $25 \mu \mathrm{m}$ in length in high power views $(\times 400)$. (B) Quantification of Mac- $2^{+}$macrophage area in EAT, SAT and BAT of mice. (C) Real-time PCR quantitative mRNA expression of macrophage marker gene F4/80 in EAT, SAT and BAT of mice. Statistical difference between groups is shown using a nonparametric Mann-Whitney test. $\mathrm{n}=8$ per group. ${ }^{*} P<0.05,{ }^{* *} P<0.01$. All data in (B)(C) are means \pm SEM.

doi: 10.1371/journal.pone.0084075.g003

$6 \mathrm{~A}$ and $6 \mathrm{~B}$ ), but not in SAT and BAT (Figure 6B). BM-contained diets suppressed the mast cell number enhancements in EAT of the mice with HFD, while there was no significantly difference among 3 groups with LFD (Figure $6 \mathrm{~A}$ and $6 \mathrm{~B}$ ). 
A

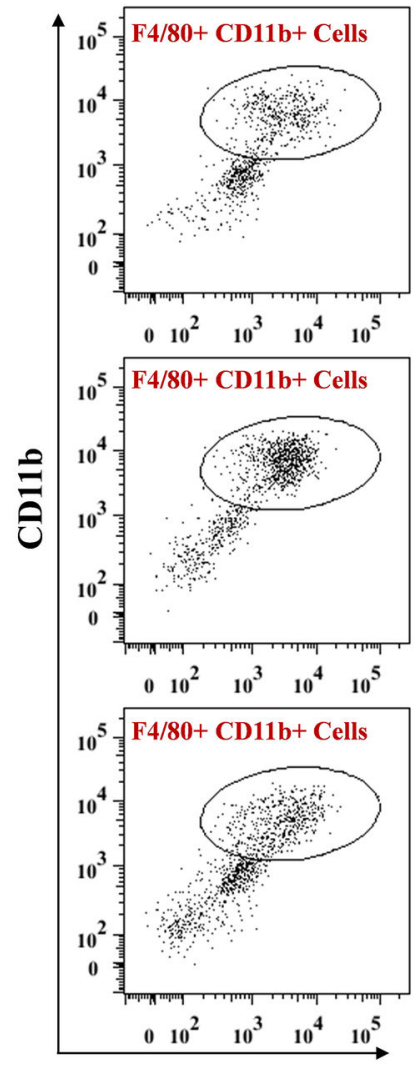

F4/80
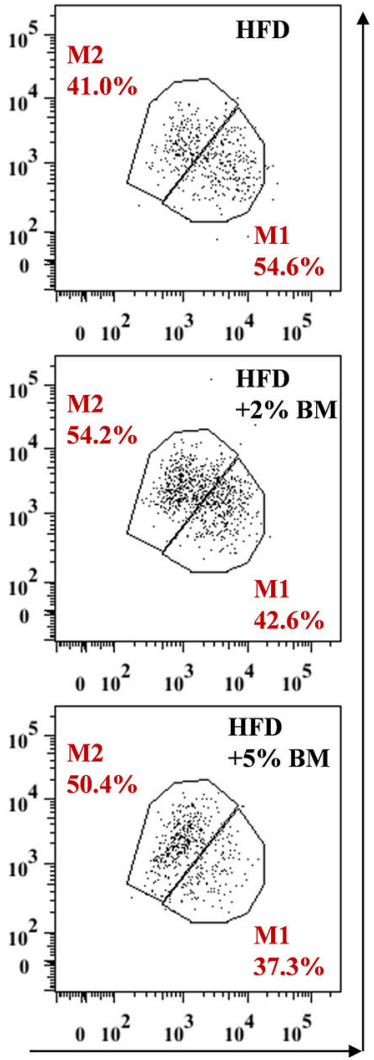

CD11c

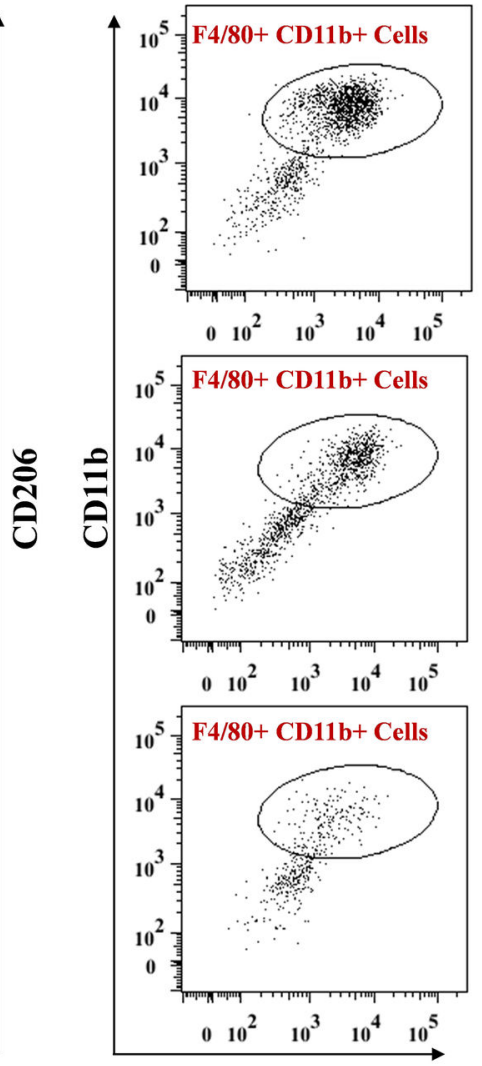

F4/80

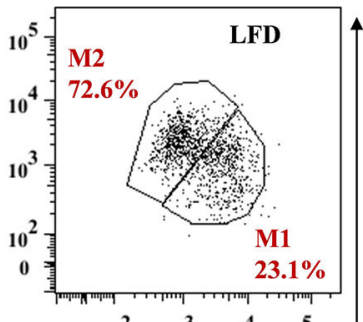

$\begin{array}{lllll}0 & 10^{2} & 10^{3} & 10^{4} & 10^{5}\end{array}$
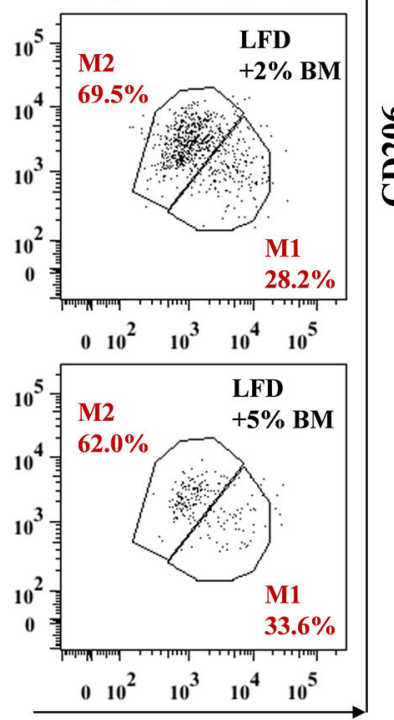

CD11c
B

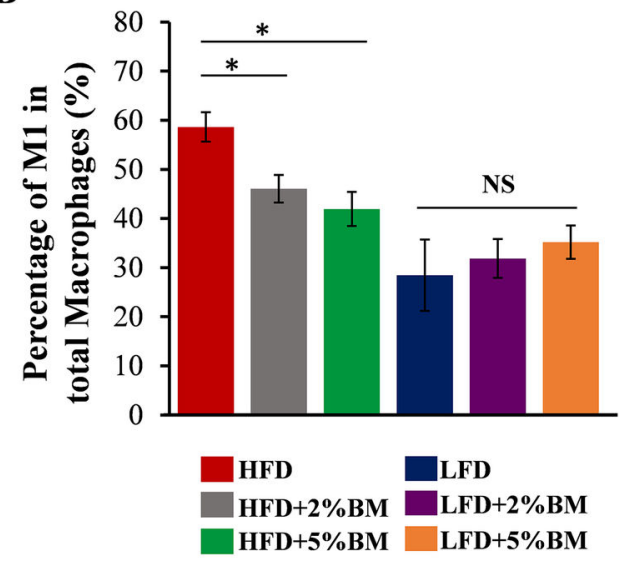

C

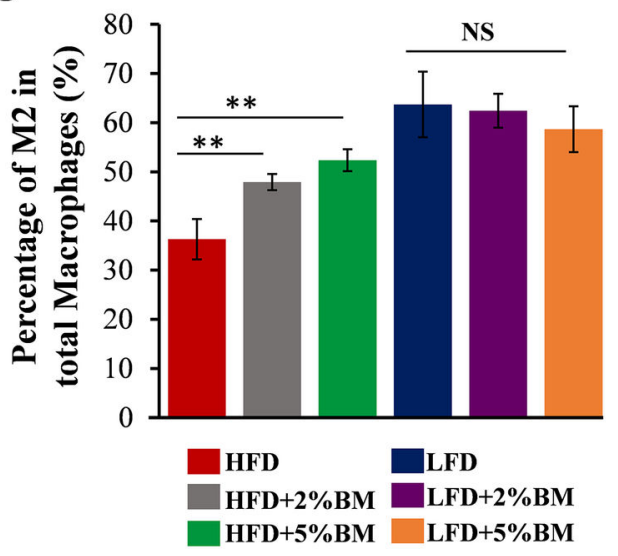

Figure 4. BM induced phenotypic switch in macrophage polarization in EAT of mice. (A) Analysis of SVF cells for M1 and M2 macrophage. SVF cells were stained with antibodies against F4/80, CD11b, CD11c, CD206, and analyzed by flow cytometry. Samples were gated for F4/80+ CD11b+ cells, then examined for coexpression of CD11C or CD206. M1 and M2 macrophage and their percentage were indicated in red. (B and C) Quantitation of percentage for M1 and M2 macrophage in total F4/80+ CD11b+ cells. Statistical difference between groups is shown using a nonparametric Mann-Whitney test. $\mathrm{n}=6$ per group. ${ }^{*} P<0.05,{ }^{* *} P<0.01$. All data in $(B)-(C)$ are means \pm SEM.

doi: 10.1371/journal.pone.0084075.g004

Correspondingly, BM-contained diets also depressed the expression of mast cell maker gene $m M c p-6$ in EAT (Figure
6C). We reported previously that genetic deficiency and pharmacological stabilization of mast cells can increase energy 


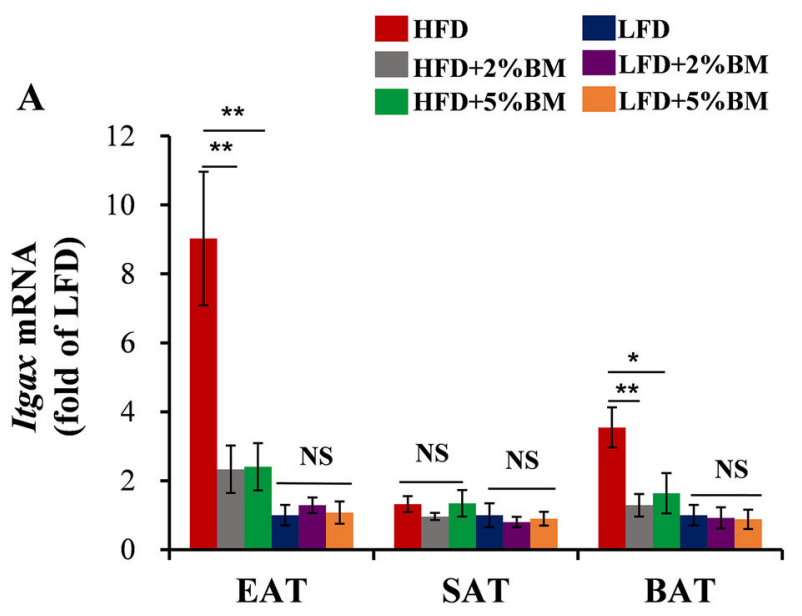

C

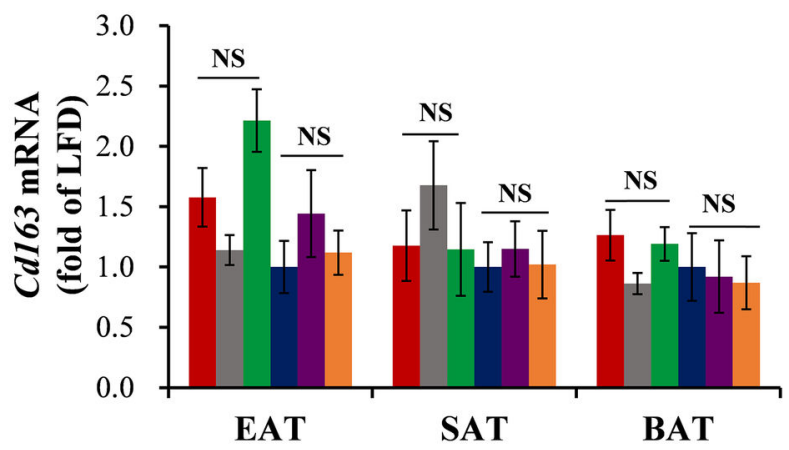

D
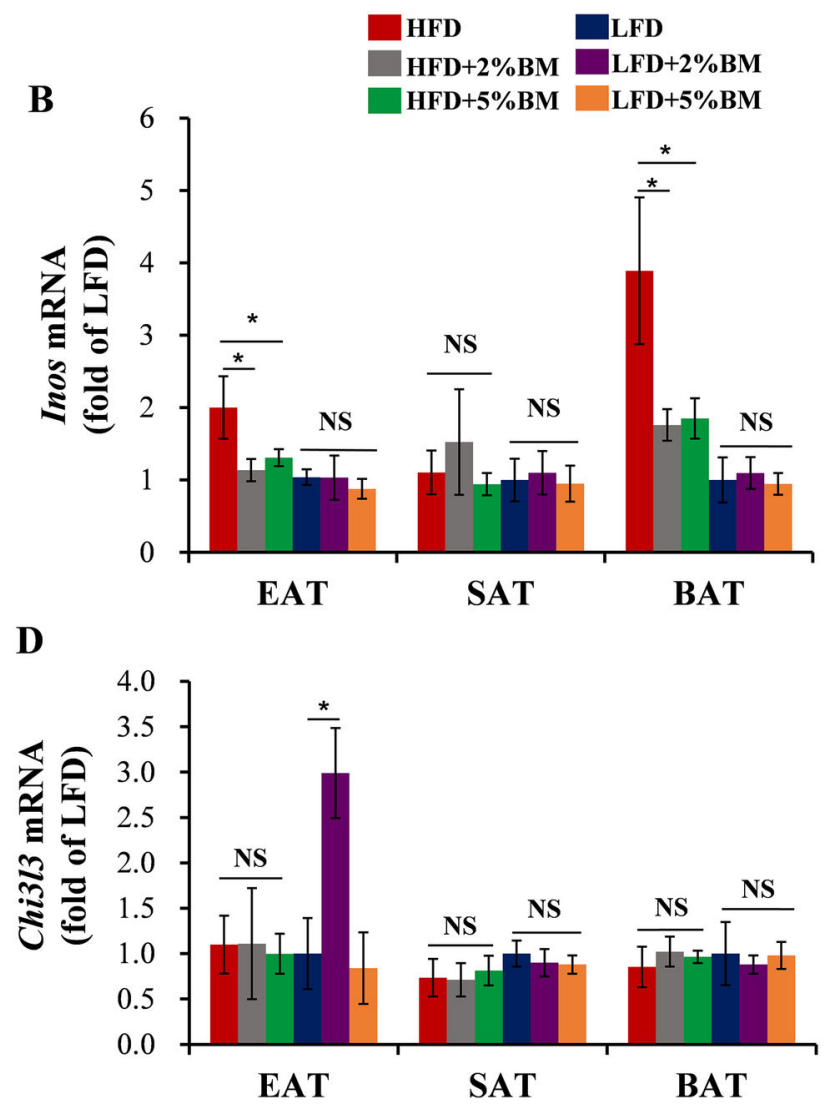

Figure 5. BM inhibited subset change of macrophages in EAT and BAT of mice. The M1 marker gene expression of macrophages Itgax (A) and Inos (B) in EAT, SAT and BAT of mice. The M2 marker gene expression of macrophages Cd163 (C) and Chi3/3 (D) in EAT, SAT and BAT of mice. Statistical difference between groups is shown using a nonparametric Mann-Whitney test. $\mathrm{n}=8$ per group. ${ }^{*} P<0.05,{ }^{* *} P<0.01$. All data in (A)-(D) are means \pm SEM.

doi: 10.1371/journal.pone.0084075.g005

expenditure and promote UCP-1 protein expression in BAT [6] Consistent with the previous results, the mice fed on HFD with $2 \%$ or $5 \%$ BM had an up-regulated Ucp-1 mRNA expression in BAT (Figure 6D), along with their less mast cell numbers in EAT.

\section{Bitter melon reduced inflammation cytokine levels in adipose tissues and sera}

To assess the effects of BM on the increased local inflammatory levels in DIO mice, we measured the mRNA expression levels of several important pro-inflammatory cytokines involved in fat deposition and insulin resistance [10], including Mcp-1, II-6 and Tnf- $\alpha$ in EAT, SAT and BAT. Realtime PCR showed HFD led to increased $M c p-1$ expression in EAT and BAT (Figure 7A), II-6 (Figure 7B) and Tnf- $\alpha$ (Figure $7 C)$ expressions in EAT and the increased expressions were suppressed by BM-contained diets in mice with HFD. And then, we tested the serum levels of these cytokines using ELISA assays, which revealed the mice fed on HFD with $2 \%$ or $5 \%$ $\mathrm{BM}$ had a similar reduction in the serum inflammatory mediator concentrations (Figure 7D). These results suggest that BM- contained diets suppress adipose tissue and system inflammation levels, and may hereby improve fat deposition and insulin resistance in DIO mice.

\section{Discussion}

BM is a traditional and functional vegetable for several metabolic diseases, including obesity and diabetes [12,13], in which chronic adipose tissue inflammation is regarded as a major factor of impaired insulin sensitivity [10,11]. Previous reports showed that $\mathrm{BM}$ or its components could reduce insulin resistance and fat deposition accompanied by obesity in different experimental conditions [14-23]. Therefore, we hypothesized BM can reduce adipose tissue inflammation in DIO mice. To test the hypothesis, we reaffirmed the antiobesity and anti-diabetes action of BM in DIO mice (Figures 1 and 2). Our results showed BM-contained diets could reduce HFD-induced body weight gain (Figure 1A) and related adipose tissue hyperplasia (Figure 1B and Figure 2), improve insulin resistance and glucose intolerance (Figure $1 \mathrm{C}$ and 1D), and lower serum levels of insulin and leptin (Figure 1E and 1F). 
A
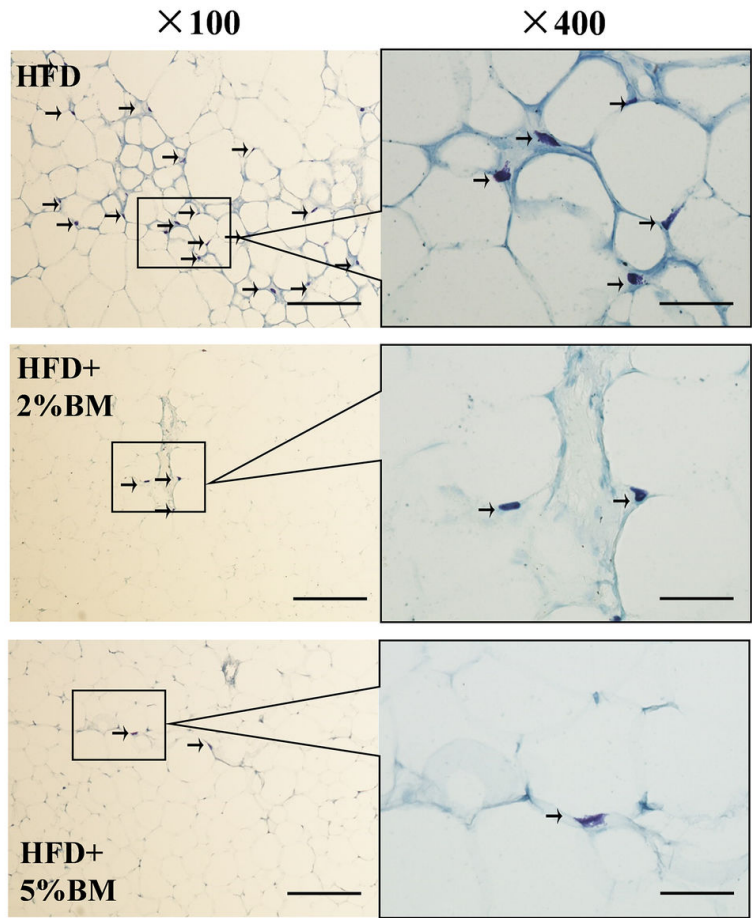

B

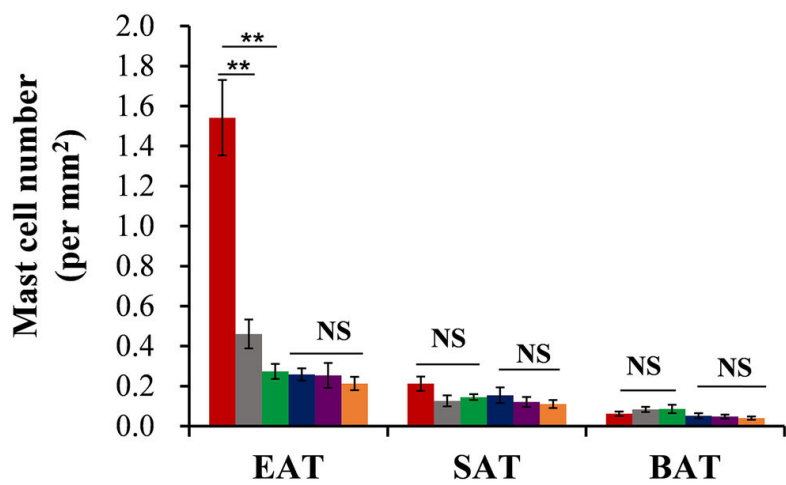

D

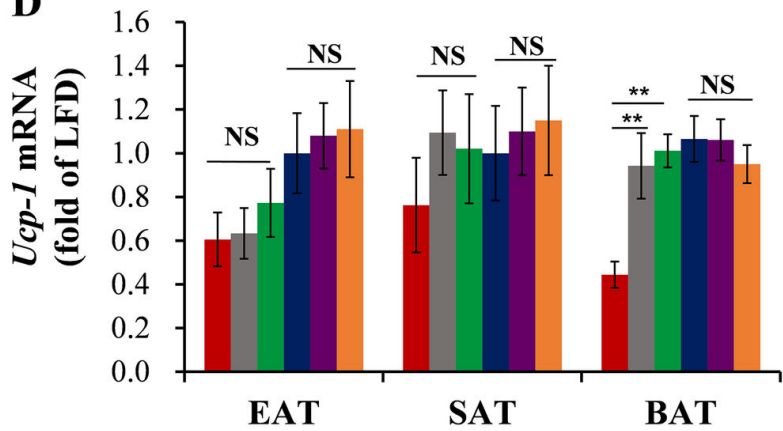

$\mathbf{C}$

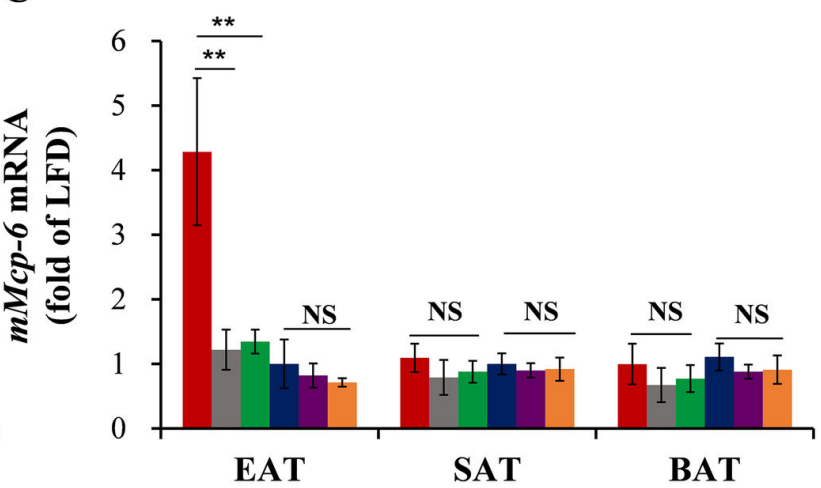

Figure 6. BM inhibited recruitment of mast cells in EAT of mice. (A)Toluidine blue staining of mast cells in EAT of mice; arrows indicate toluidine blue staining mast cells; scale bars in (A), 100 $\mathrm{m}$ in length in low power views $(\times 100)$ and $25 \mu \mathrm{m}$ in length in high power views $(\times 400)$. (B) The quantification of the numbers of mast cells in EAT, SAT and BAT of mice. (C) The expression of mast cell marker gene mMcp-6 in EAT, SAT and BAT of mice. (D) The expression of energy expenditure marker gene Ucp-1 in EAT, SAT and BAT of mice. Statistical difference between groups is shown using a nonparametric Mann-Whitney test. $\mathrm{n}=8 \mathrm{per}$ group. ${ }^{\star} P<0.05,{ }^{* *} P<0.01$. All data in (B)-(D) are means \pm SEM.

doi: 10.1371/journal.pone.0084075.g006 

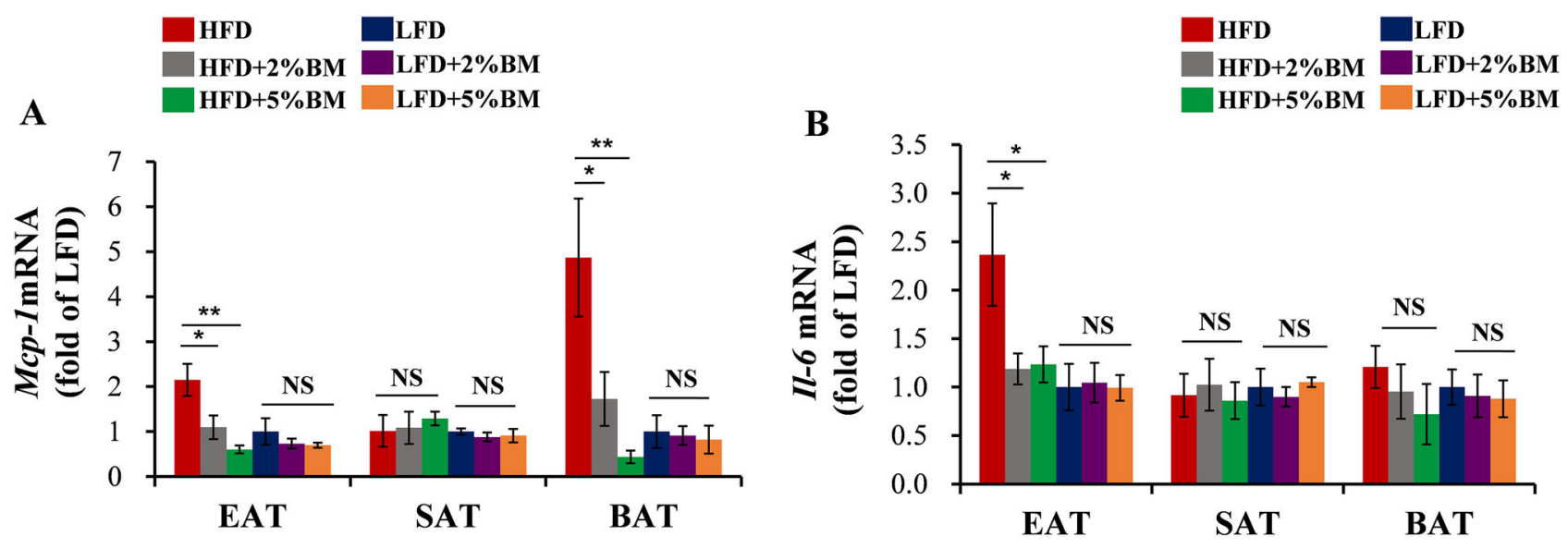

C

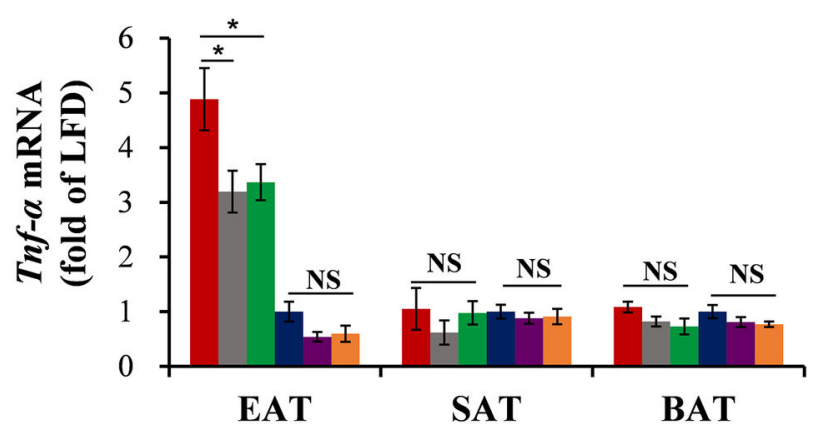

D

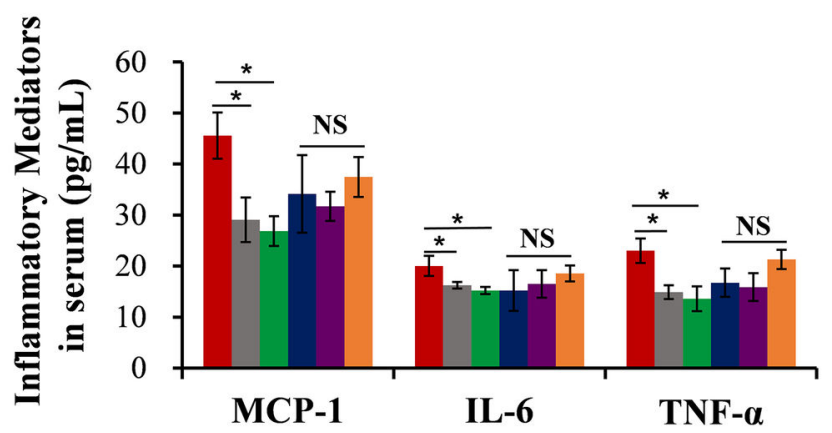

Figure 7. BM down-regulated inflammation mediator levels in adipose tissues and serum of mice. The mRNA expression of $M c p-1$ (A), II-6 (B) and Tnf- $\alpha(C)$ in EAT, SAT and BAT of mice. (D) The inflammation mediator concentrations in serum were measured by mouse MCP-1, IL-6 and TNF- $\alpha$ ELISA kit of mice. Statistical difference between groups is shown using a nonparametric Mann-Whitney test. $\mathrm{n}=8$ per group. ${ }^{*} P<0.05,{ }^{* *} P<0.01$. All data in (A)-(D) are means \pm SEM.

doi: 10.1371/journal.pone.0084075.g007

In bodies of humans and rodents, there are various specific functional and locational adipose tissues, such as visceral adipose tissues, SAT and BAT $[10,27]$. Both visceral and subcutaneous adipose tissues are white adipose depots, but they are really distinct in obesity-associated inflammation. Responding to HFD, visceral adipose tissues, for example EAT, possess more inflammatory cell recruitments and secrete more abundant pro-inflammatory mediators than SAT $[10,11]$. While BAT play a critical role in energy expenditure as the primary thermogenesis regulator, HFD can induce BAT to exhibit more inflammatory and immune responses [28]. Since BM-contained diets can reduce diet-induced obesity and may hereby affect inflammation levels in these various adipose tissues, we studied a detailed inflammatory profile, including macrophages, mast cells and some pro-inflammatory cytokines in EAT, SAT and BAT.

Using anti-Mac-2 monoclonal antibody, we firstly performed immunohistochemistry analysis of adipose tissue macrophages, which have garnered the most attention in adipose tissue inflammation [10,11,29]. BM-contained diets significantly inhibited the infiltration of macrophages into EAT and BAT (Figure 3) in mice with HFD. It is well known that a macrophage sub-type shift from M2-polarized type to M1 proinflammatory type occurs in adipose tissue of experiment animals, along with diet-induced body weight gain and insulin resistance $[9,26]$. Therefore, using mutlicolour flow cytometry, we analyzed macrophage polarization in EAT. BM significantly induced a switch of M1 to M2 in EAT from mice fed with HFD (Figure 4). We also examined the expression of some macrophage or macrophage subtype specific genes in above mouse adipose tissues using real-time PCR. We found that the maker gene of total macrophage $F 4 / 80$ expression levels were lower in EAT and BAT in mice fed on BM-contained HFD than those in mice fed only on HFD (Figure $3 C$ ), supporting our above immunostaining using antibody to Mac-2 (Figure $3 \mathrm{~A}$ and 3B). Moreover, the increased expression levels of $M 1$ macrophage specific genes Itgax and Inos were reversed by BM-contained diets in EAT and BAT in mice with HFD (Figure $5 A$ and $5 B$ ) and the expression levels of $M 2$ macrophage specific genes Cd163 and Chil3l were not changed in the tissues (Figure 5C and 5D). The data indicate that BMcontained diets reduce not only total macrophage distribution 
levels but also the sub-type radio of M1/M2 macrophages in EAT and BAT of DIO mice, which may protect those body weight reduced mice from enhanced adipose tissue inflammation.

Once mast cells were known for their playing a critical role in immunoglobulin E-associated allergic disorders, recent studies show the inflammatory cells are involved in pathogenesis of metabolic diseases, such as obesity, diabetes and atherosclerosis [6,30,31]. We previously reported that there are more mast cells in EAT in DIO mice than those in lean mice and described the possible mechanisms that the cells promote diet-induced obesity and glucose intolerance [6]. Using toluidine blue histological analysis, we re-presented the HFDinduced mast cell number enhancement in EAT (Figure 6A and $6 B)$. Further, we found that BM-contained diets significantly reduced the number of mast cells and the mRNA expression level of mast cell maker gene $m M c p-6$ in EAT in mice fed with HFD (Figure 6A-6C). Interestingly, along with less mast cells, BM-contained diets up-regulated the mRNA expression of energy expenditure maker gene $U_{c p}-1$ in BAT in mice fed on HFD (Figure 6D). The phenomena not only supported our pervious reports that genetic deficiency and pharmacological stabilization of mast cells enhanced energy expenditure in mice [6], but also suggested that BM-contained diets might ameliorate insulin resistance and fat deposition by suppressing mast cell infiltration and hereby improving energy expenditure in DIO mice.

However, unlike BM-contained HFD, BM-contained LFD had no effect on physiology indexes (Figure 1 Figure 2) in mice, this may due to absent adipose inflammation in LFD-fed mice. This results supported that BM could reduce HFD-induced body weight gain through ameliorating adipose tissue inflammation in mice. When added to low fat diet, BM had no effect on macrophage (Figure 3) and mast cell (Figure 6) infiltration, and sub-type radio of M1/M2 macrophages (Figure 4 and Figure 5) in EAT, SAT and BAT. The results suggested that BM could reduce inflammatory cells infiltration and polarization in mice on HFD, but not affect the behaviors of inflammatory cells in healthy mice.

Nerukar et al. recently reported that diets supplemented with freeze dried BM juice (BMJ) improved HFD-induced neuroinflammation [24]. They used cytokine antibody array to show that BMJ diet supplement reduced plasma levels of some important pro-inflammatory cytokines implicated in obesityassociated adipose tissue inflammation [10], such as IL-6, TNF- $\alpha$ and MCP-1 in mice with HFD. To examine whether whole BM fruit (WBF) diet supplement can impact adipose tissue inflammatory cytokine levels, we use real-time PCR to test the mRNA expression of Mcp-1, II- 6 and Tnf- $\alpha$ in EAT, SAT and BAT. The results showed that BM-contained diets lower Mcp-1 expression in EAT and BAT as well as $I-6$ and Tnf- $\alpha$ expression in BAT in the mice fed on HFD (Figure 7A-C). Further, ELISA assays indicated the lower levels of their corresponding protein in sera of the mice (Figure 7D). In adipose tissues, the pro-inflammatory cytokines, which were up-regulated by HFD and normalized by BM, can be expressed in both adipocytes and stromal vascular cells, including macrophages and mast cells. We can't conclude which cells express and secrete the cytokines in adipose tissues, but BMregulated adipose tissue inflammatory cell and proinflammatory cytokine reduction might be involved in improvement of insulin resistance and fat deposition in DIO mice.

Unlike our above results, a recent study showed that diets supplemented with BM seed (BMS) oil increased TNF- $\alpha$ concentration and macrophage crown-like structure number in EAT in mice with HFD, along with reduced body weight gain and unaffected serum glucose and insulin levels in the mice [32]. It seems that BMS contain more distinctive proinflammatory ingredients than other portion of BM fruits, while whole BM fruits preparation, such as WBF and BMJ, present a holistic anti-inflammatory characteristic, which may lead to the difference of BM fruits and BMS in biological function. Indeed, our here study and other studies have showed WBF $[15,22]$ or BMJ $[18,23,33,34]$ can effectively inhibit obesity and obesityassociated insulin resistance in DIO animals, while BMS preparation only exhibited one-sided effects on obesity [32] and blood glucose enhancement [35].

BM contains many active ingredients, including steroid and triterpenoid glycosides, alkaloids, flavonoids, polyphenols, carotenoids, fatty acids, and some active polypeptides (including insulin-like peptides) [36-38]. In these chemicals, the idiographic comments inhibit obesity-associated adipose tissue inflammation is not known, but some of them have showed potential related activities. Anti-diabetic activities of some triterpenoids from BM have been reported [14,39,40]. Although it isn't clear whether their anti-diabetic actions have any correlations with obesity-associated adipose tissue inflammation, some hypoglycemic triterpenes have been showed an effective inhibitory activity to TNF-a-induced insulin resistance and inflammation in hepatic cell FL83B $[41,42]$. Moreover, a potent macrophage inflammation inhibitor [43] and mast cell stabilizer [44] quercetin were also found in BM fruits $[24,45]$.

In summary, our results present the effects of BM on adipose tissue inflammation in DIO mice. BM reduced the adipocyte hyperplasia, recruitments of inflammatory M1-type macrophages and mast cells into EAT and/or BAT, might hereby suppress adipose tissue and system inflammation levels. Targeting special functional components of BM and their mechanism to regulate tissue and system inflammation may have therapeutic potential to prevent or reduce the development of obesity-associated complications, a hypothesis that merits further investigation in experimental animals and humans.

\section{Author Contributions}

Conceived and designed the experiments: BB YGC JL. Performed the experiments: BB YGC LZ YL XW. Analyzed the data: BB YGC LZ YL NX. Wrote the manuscript: BB YGC WQ JL. 


\section{References}

1. Grundy SM (2002) Obesity, metabolic syndrome, and coronary atherosclerosis. Circulation 105: 2696-2698. doi:10.1161/01.CIR. 0000020650.86137.84. PubMed: 12057978

2. Franks PW, Hanson RL, Knowler WC, Sievers ML, Bennett PH et al. (2010) Childhood obesity, other cardiovascular risk factors, and premature death. $\mathrm{N}$ Engl J Med 362: 485-493. doi:10.1056/ NEJMoa0904130. PubMed: 20147714.

3. Wang YC, McPherson K, Marsh T, Gortmaker SL, Brown M (2011) Health and economic burden of the projected obesity trends in the USA and the UK. Lancet 378: 815-825. doi:10.1016/ S0140-6736(11)60814-3. PubMed: 21872750.

4. Weisberg SP, McCann D, Desai M, Rosenbaum M, Leibel RL et al. (2003) Obesity is associated with macrophage accumulation in adipose tissue. J Clin Invest 112: 1796-1808. doi:10.1172/JCI19246. PubMed: 14679176 .

5. Altintas MM, Azad A, Nayer B, Contreras G, Zaias J et al. (2011) Mast cells, macrophages, and crown-like structures distinguish subcutaneous from visceral fat in mice. J Lipid Res 52: 480-488. doi: 10.1194/jlr.M011338. PubMed: 21148461.

6. Liu J, Divoux A, Sun J, Zhang J, Clément K et al. (2009) Genetic deficiency and pharmacological stabilization of mast cells reduce dietinduced obesity and diabetes in mice. Nat Med 15: 940-945. doi: 10.1038/nm.1994. PubMed: 19633655.

7. Wu H, Ghosh S, Perrard XD, Feng L, Garcia GE et al. (2007) T-cell accumulation and regulated on activation, normal $\mathrm{T}$ cell expressed and secreted upregulation in adipose tissue in obesity. Circulation 115: 1029-1038. doi:10.1161/CIRCULATIONAHA.106.638379. PubMed: 17296858.

8. Chatzigeorgiou A, Karalis KP, Bornstein SR, Chavakis T (2012) Lymphocytes in obesity-related adipose tissue inflammation. Diabetologia 55: 2583-2592. doi:10.1007/s00125-012-2607-0. PubMed: 22733483

9. Lumeng CN, Bodzin JL, Saltiel AR (2007) Obesity induces a phenotypic switch in adipose tissue macrophage polarization. $\mathrm{J}$ Clin Invest 117: 175-184. doi:10.1172/JCl29881. PubMed: 17200717.

10. Ouchi N, Parker JL, Lugus JJ, Walsh K (2011) Adipokines in inflammation and metabolic disease. Nat Rev Immunol 11: 85-97. doi: 10.1038/nri2921. PubMed: 21252989.

11. Osborn O, Olefsky JM (2012) The cellular and signaling networks linking the immune system and metabolism in disease. Nat Med 18: 363-374. doi:10.1038/nm.2627. PubMed: 22395709

12. Leung L, Birtwhistle R, Kotecha J, Hannah S, Cuthbertson S (2009) Anti-diabetic and hypoglycaemic effects of Momordica charantia (bitter melon): a mini review. $\mathrm{Br} \mathrm{J}$ Nutr 102: 1703-1708. doi:10.1017/ S0007114509992054. PubMed: 19825210.

13. Fang EF, Ng TB (2011) Bitter gourd (Momordica charantia) is a cornucopia of health: a review of its credited antidiabetic, anti-HIV, and antitumor properties. Curr Mol Med 11: 417-436. doi: 10.2174/156652411795976583. PubMed: 21568930

14. Tan MJ, Ye JM, Turner N, Hohnen-Behrens C, Ke CQ et al. (2008) Antidiabetic activities of triterpenoids isolated from bitter melon associated with activation of the AMPK pathway. Chem Biol 15: 263-273. doi:10.1016/j.chembiol.2008.01.013. PubMed: 18355726.

15. Iseli TJ, Turner N, Zeng X-Y, Cooney GJ, Kraegen EW et al. (2013) Activation of AMPK by Bitter Melon Triterpenoids Involves CaMKKb. PLOS ONE 8(4): e62309. doi:10.1371/journal.pone.0062309. PubMed: 23638033

16. Shih CC, Lin CH, Lin WL (2008) Effects of Momordica charantia on insulin resistance and visceral obesity in mice on high-fat diet. Diabetes Res Clin Pract 81: 134-143. doi:10.1016/j.diabres.2008.04.023. PubMed: 18550200.

17. Chao CY, Yin MC, Huang CJ (2011) Wild bitter gourd extract upregulates mRNA expression of PPARalpha, PPARgamma and their target genes in C57BL/6J mice. J Ethnopharmacol 135: 156-161. doi: 10.1016/j.jep.2011.03.001. PubMed: 21392566.

18. Nerurkar PV, Lee YK, Motosue M, Adeli K, Nerurkar VR (2008) Momordica charantia (bitter melon) reduces plasma apolipoprotein B-100 and increases hepatic insulin receptor substrate and phosphoinositide-3 kinase interactions. $\mathrm{Br} \mathrm{J}$ Nutr 100: 751-759. PubMed: 18321395

19. Klomann SD, Mueller AS, Pallauf J, Krawinkel MB (2010) Antidiabetic effects of bitter gourd extracts in insulin-resistant $\mathrm{db} / \mathrm{db}$ mice. $\mathrm{Br} \mathrm{J}$ Nutr 104: 1613-1620. doi:10.1017/S0007114510002680. PubMed: 20615270.

20. Wang ZQ, Zhang XH, Yu Y, Poulev A, Ribnicky D et al. (2011) Bioactives from bitter melon enhance insulin signaling and modulate acyl carnitine content in skeletal muscle in high-fat diet-fed mice. J Nutr
Biochem 22: 1064-1073. doi:10.1016/j.jnutbio.2010.09.004. PubMed: 21277185

21. Sridhar MG, Vinayagamoorthi R, Arul Suyambunathan V, Bobby Z, Selvaraj N (2008) Bitter gourd (Momordica charantia) improves insulin sensitivity by increasing skeletal muscle insulin-stimulated IRS-1 tyrosine phosphorylation in high-fat-fed rats. $\mathrm{Br} J$ Nutr 99: 806-812. PubMed: 17942003

22. Huang HL, Hong YW, Wong YH, Chen YN, Chyuan JH et al. (2008) Bitter melon (Momordica charantia L.) inhibits adipocyte hypertrophy and down regulates lipogenic gene expression in adipose tissue of dietinduced obese rats. Br J Nutr 99: 230-239. PubMed: 17651527.

23. Chan LL, Chen Q, Go AG, Lam EK, Li ET (2005) Reduced adiposity in bitter melon (Momordica charantia)-fed rats is associated with increased lipid oxidative enzyme activities and uncoupling protein expression. J Nutr 135: 2517-2523. PubMed: 16251604.

24. Nerurkar PV, Johns LM, Buesa LM, Kipyakwai G, Volper E et al. (2011) Momordica charantia (bitter melon) attenuates high-fat diet-associated oxidative stress and neuroinflammation. J Neuroinflammation 8: 64 . doi:10.1186/1742-2094-8-64. PubMed: 21639917.

25. Yu W, Liu J, Shi MA, Wang J, Xiang M et al. (2010) Cystatin C deficiency promotes epidermal dysplasia in K14-HPV16 transgenic mice. PLOS ONE 5: e13973. doi:10.1371/journal.pone.0013973. PubMed: 21085595

26. Dalmas E, Clément K, Guerre-Millo M (2011) Defining macrophage phenotype and function in adipose tissue. Trends Immunol 32: 307-314. doi:10.1016/j.it.2011.04.008. PubMed: 21616718.

27. Rosen ED, Spiegelman BM (2006) Adipocytes as regulators of energy balance and glucose homeostasis. Nature 444: 847-853. doi:10.1038/ nature05483. PubMed: 17167472.

28. Hageman RS, Wagener A, Hantschel C, Svenson KL, Churchill GA et al. (2010) High-fat diet leads to tissue-specific changes reflecting risk factors for diseases in DBA/2J mice. Physiol Genomics 42: 55-66. doi: 10.1152/physiolgenomics.00072.2009. PubMed: 20215417.

29. Olefsky JM, Glass CK (2010) Macrophages, inflammation, and insulin resistance. Annu Rev Physiol 72: 219-246. doi:10.1146/annurevphysiol-021909-135846. PubMed: 20148674.

30. Wang J, Shi GP (2011) Mast cell stabilization: novel medication for obesity and diabetes. Diabetes Metab Res Rev 27: 919-924. PubMed: 22069285

31. Sun J, Sukhova GK, Wolters PJ, Yang M, Kitamoto S et al. (2007) Mast cells promote atherosclerosis by releasing proinflammatory cytokines. Nat Med 13: 719-724. doi:10.1038/nm1601. PubMed: 17546038

32. Chen PH, Chen GC, Yang MF, Hsieh CH, Chuang SH et al. (2012) Bitter melon seed oil-attenuated body fat accumulation in diet-induced obese mice is associated with cAMP-dependent protein kinase activation and cell death in white adipose tissue. J Nutr 142: 1197-1204. doi:10.3945/jn.112.159939. PubMed: 22623391.

33. Chen Q, Li ET (2005) Reduced adiposity in bitter melon (Momordica charantia) fed rats is associated with lower tissue triglyceride and higher plasma catecholamines. Br J Nutr 93: 747-754. doi:10.1079/ BJN20051388. PubMed: 15975176.

34. Chen Q, Chan LL, Li ET (2003) Bitter melon (Momordica charantia) reduces adiposity, lowers serum insulin and normalizes glucose tolerance in rats fed a high fat diet. J Nutr 133: 1088-1093. PubMed: 12672924.

35. Gadang V, Gilbert W, Hettiararchchy N, Horax R, Katwa L et al. (2011) Dietary Bitter Melon Seed Increases Peroxisome Proliferator-Activated Receptor-c Gene Expression in Adipose Tissue, Down-Regulates the Nuclear Factor-kB Expression, and Alleviates the Symptoms Associated with Metabolic Syndrome. J Med Food 14: 86-93. doi: 10.1089/jmf.2010.0010. PubMed: 21128828

36. Anila L, Vijayalakshmi NR (2000) Beneficial effects of flavonoids from Sesamum indicum, Emblica officinalis and Momordica charantia. Phytother Res 14: 592-595. doi:10.1002/1099-1573(200012)14:8. PubMed: 11113993.

37. Grover JK, Yadav SP (2004) Pharmacological actions and potential uses of Momordica charantia: a review. J Ethnopharmacol 93: 123-132. doi:10.1016/j.jep.2004.03.035. PubMed: 15182917.

38. Singh J, Cumming E, Manoharan G, Kalasz H, Adeghate E (2011) Medicinal chemistry of the anti-diabetic effects of Momordica charantia: active constituents and modes of actions. Open Med Chem. J. 5(Suppl 2): 70-77.

39. Harinantenaina L, Tanaka M, Takaoka S, Oda M, Mogami O et al. (2006) Momordica charantia constituents and antidiabetic screening of the isolated major compounds. Chem Pharm Bull (Tokyo) 54: 1017-1021. doi:10.1248/cpb.54.1017. PubMed: 16819222. 
40. Keller AC, Ma J, Kavalier A, He K, Brillantes AM et al. (2011) Saponins from the traditional medicinal plant Momordica charantia stimulate insulin secretion in vitro. Phytomedicine 19: 32-37. doi:10.1016/ j.phymed.2011.06.019. PubMed: 22133295.

41. Cheng HL, Kuo CY, Liao YW, Lin CC (2012) EMCD, a hypoglycemic triterpene isolated from Momordica charantia wild variant, attenuates TNF-alpha-induced inflammation in FL83B cells in an AMP-activated protein kinase-independent manner. Eur J Pharmacol 689: 241-248. doi:10.1016/j.ejphar.2012.05.033. PubMed: 22683870.

42. Chang $\mathrm{Cl}$, Tseng HI, Liao YW, Yen $\mathrm{CH}$, Chen TM et al. (2011) In vivo and in vitro studies to identify the hypoglycemic constituents of
Momordica charantia wild variant WB24. Food Chemistry 125: 521528. doi:10.1016/j.foodchem.2010.09.043.

43. Overman A, Chuang CC, McIntosh M (2011) Quercetin attenuates inflammation in human macrophages and adipocytes exposed to macrophage-conditioned media. Int J Obes (Lond) 35: 1165-1172. doi: 10.1038/ijo.2010.272. PubMed: 21224828.

44. Sismanopoulos N, Delivanis DA, Alysandratos KD, Angelidou A, Therianou A et al. (2012) Mast cells in allergic and inflammatory diseases. Curr Pharm Des 18: 2261-2277. doi: 10.2174/138161212800165997. PubMed: 22390690.

45. Nerurkar PV, Lee YK, Nerurkar VR (2010) Momordica charantia (bitter melon) inhibits primary human adipocyte differentiation by modulating adipogenic genes. BMC Complement Altern Med 10: 34 . doi: 10.1186/1472-6882-10-34. PubMed: 20587058. 